Original Paper

\title{
Penyusunan Proposal Penelitian Tindakan Kelas (PTK) Bagi Guru-Guru MTs dan MA Di Kecamatan Woja Kabupaten Dompu
}

\author{
Hamidsyukrie $\mathbf{Z M}^{*}$, Sukardi ${ }^{2}$, Ni Made Novi Suryanti ${ }^{1}$ \\ ${ }^{1}$ Program Studi Pendidikan Sosiologi FKIP, Unirversitas Mataram, Mataram \\ ${ }^{2}$ Pascasarjana Universitas Mataram, Mataram
}

*Corresponding Author:

Hamidsyukrie ZM, Program Studi Pendidikan Sosiologi FKIP, Unirversitas Mataram, Mataram, Indonesia;

Email:

hamidsyukrie60@gmail.com

\begin{abstract}
Abstrak: Tujuan kegiatan pengabdian ini adalah untuk meningkatkan pengetahuan dan keterampilan guru-guru MA dan MTs Swasta di Kecamatan Woja Kabupaten Dompu dalam membuat proposal penelitian tindakan kelas (PTK). Untuk mencapai tujuan ini, kegiatan ini menggunakan metode workshop melalui cara pelatihan dan pendampingan. Hasilnya menunjukkan bahwa guruguru mampu mengikuti rangkaian kegiatan dan mampu membuat proposal PTK. Kegiatan disambut baik oleh guru-guru dan mereka mengharapkan agar kegiatan serupa dapat dilakukan secara periodik.
\end{abstract}

Kata Kunci: Penyusunan Proposal, Penelitian Tindakan Kelas

\section{Pendahuluan}

Merujuk pada Peraturan Menteri Negara Pendayagunaan Aparatur Negara dan Reformasi Birokrasi Nomor 16 Tahun 2009 tentang Jabatan Fungsional Guru dan Angka Kreditnya. Implementasinya lebih lanjut diatur dalam Permendiknas Nomor 35 Tahun 2010. Implementasi dari peraturan itu mulai diterapkan pada tahun 2013 mulai bulan Oktober yang mewajibakan guru memiliki publikasi ilmiah dan atau karya inovatif bagi yang akan naik pangkat. Adanya peraturan tersebut berimplikasi bagi guruguru untuk meningkatkan keprofesiannya yang berkelanjutan bagi pengembangan dirinya melalui penyusunan publikasi ilmiah dan publikasi inovatif. Guru yang inovatif, kreatif,dan produktif adalah guru yang selalu mencari dan menemukan hal-hal baru dan mutakhir untuk kepentingan kualitas pembelajaran di kelas (Sunyono,2007).

Publikasi karya ilmiah guru meliputi: laporan hasil penelitian diseminarkan di sekolahnya disimpan di perpustakaan, tinjauan ilmiah tidak diterbitkan disimpan di perpustakaan, artikel ilmiah populer dimuat di media masa tingkat nasional/provinsi, artikel Ilmiah dimuat di jurnal tingkat nasional /propvinsi/ kabupaten/ kota, Buku pelajaran yang lolos BSNP/ber-ISBN/belum
ber-ISBN, dll. Karya inovatif meliputi: menemukan teknologi tepat guna, menemukan /menciptakan karya seni; membuat/ memodifikasi alat pelajaran/ peraga /praktikum; dan mengikuti pengembangan penyusunan standar, pedoman, soal dan sejenisnya.

Akan tetapi, harapan besar di atas tidak sesuai dengan realitas di lapangan. Permasalahanpermasalahan yang terkait dengan hal ini berasal langsung dari guru sendiri seperti kurangnya motivasi dan kemauan guru untuk membaca ataupun keinginan menulis. Hal ini berdampak pada kemampuan untuk membuat proposal penelitian. Berdasarkan pada kegiatan pelatihan guru-guru (PLPG) Kementerian Agama (Kemenag) tingkat madrasah ditemukan permasalahan umum yang dihadapi oleh guru-guru MTS-MA, yaitu belum memahami cara penyusunan penelitian Tindakan Kelas (PTK) . Kondisi tersebut ditemukan juga oleh tim pengabdian kepada Masyarakat di MTS-MA Kecamatan Woja Kabupaten Dompu.

Dari studi pendahuluan berhasil diidentifikasi permasalahan-permasalahan, yaitu kemampuan guru MTS-MA Kecamatan Woja Kabupaten Dompu masih rendah dalam menyusun proposal penelitian. Keamampuan yang rendah ini teridentifikasi melalui pengamatan bahwa guru kurang bisa menentukan judul yang tepat, cara menyusun variabel penelitian, cara identifikasi 
masalah dan perumusan masalah, penentuan metode penelitian, penulisan kutipan, dan daftar pustaka. Namun inti permasalahannya, yaitu guru belum memahami sama sekali cara dan prosedur penyusunan Penelitian Tindakan Kelas (PTK). Padahal PTK adalah bentuk refleksi diri yang dilakukan oleh para partisipan (guru, siswa, atau kepala sekolah) dalam situasi pendidikan untuk memperbaiki rasionalitas dan kebenaran (Kemmis, 1988, Sujana, 2010).

\section{Metode Pelaksanaan}

Permasalah yang dihadapi guru ini diselesaikan dengan cara melakukan workshop dengan difokuskan pada kegiatan latihan (praktik dan presentasi hasil) yang didahului pemberian materi melalui metode ceramah, dialog, diskusi. Kegiatan pengabdian ini memiliki target dan luaran. Adapun target dan luarhan yang ingin dicapai dalam kegiatan ini adalah guru-guru MTS-MA di Kecamatan Woja Kabupaten Dompu dengan harapan nantinya mereka memiliki kemampuan dalam menyusun proposal PTK. Luarannya adalah meningkatnya kemampuan guru mitra MTS-MA di Kecamatan Woja Kabupaten Dompu dalam menyusun proposal PTK.

\section{Hasil dan Pembahasan}

\section{Analisis Hasil}

Selama melakukan kegiatan pengabdian masyarakat bagi guru-guru MTS di Kecamatan MTS-MA di Kecamatan Woja Kabupaten Dompu, menunjukkan hasil yang cukup baik walaupun belum sepenunya mencapai hasil yang optimal. Berikut ini dipaparkan hasil kegiatan yang sudah dilakukan antara lain: 1) Guru-guru MTS-MA di Kecamatan Woja Kabupaten Dompu sangat antusias selama kegiatan berlangsung. Hal ini diperhatikan dari keterlibatan pimpinan sekolah beserta seluruh guru. Padahal sudah ditentukan jumlah perwakilan yang hadir mengikuti kegiatan; 2) Selama kegiatan berlangsung banyak para peserta dari guru yang mengajukan pertanyaan, tanggapan, pendapat, usulan, meminta bimbingan, memberikan komentar serta mengharap agar kegiatan ini tidak berhenti pada saat pengabdian kepada masyarakat saja namun dapat ditindaklanjuti melalui kegitan-kegiatan yang lain seperti Workshop. Adapun materi yang disampaikan berupa pengertian PTK, karakteristik PTK, tujuan PTK, manfaat PTK, Prinsip PTK, Prosedur PTK, identifikasi masalah, landasan hipotesis tindakan, jenis metode dan sumber data, menentukan Indikator kinerja, penulisan Karya Ilmiah. Semua materi tersebut sudah ada bagian masing-masing dari tim pengabdian kepada masyarakat; 3) Selama kegiatan berlangsung para peserta sangat tekun mendengar, mencatat, berlatih, mencoba,dan mengkomunikasi kembali yang sudah disampaikan oleh tim pengabdian kepada masyarakat serta tidak lupa memberikan masukan atau berbagi mengenai pengalaman mereka dalam mengadapi segala yang terkait dengan permasalahan di kelas; 4) Para peserta memberikan pandangan bahwa kegiatan yang dilakukan ini sangat memberikan masukan yang cukup banyak mengenai hal-hal yang terkait dengan Penelitian Tindakan Kelas (PTK) termasuk teknik penulisan karya ilmiah, apalagi ada tuntutan yang mewajibkan mereka menyusun.

\section{Faktor Pendukung}

Ada beberapa hal yang menjadi faktor penting sebagai pendukung dari kegiatan ini sehingga dapat dilaksanakan sesuai dengan prosedur. Upaya-upaya itu antara lain: 1) Adanya inisiatif dari para guru yang ada MTS-MA di Kecamatan Woja Kabupaten Dompu agar diberikan pelatihan Penyusunan Proposal Penelitian Tindakan Kelas (PTK); 2) para guru di MTS-MA di Kecamatan Woja Kabupaten Dompu masih kurang pengetahuan bagaimana cara menyusun proposal penelitian tindakan kelas (PTK) termasuk teknik penulisan; 3) adanya keinginan yang kuat dari pihak sekolah dalam hal ini kepala sekolah beserta guru-guru agar bisa menyusun karya tulis ilmiah seperti PTK dikarenakan itu sebagai tuntutan dan profesi yang harus dilaksanakan.

\section{Faktor Penghambat}

Walaupun kegiatan sudah dilaksanakan cukup berhasil, tetapi tidak lepas dari penghambat atau kendala yang dihadapi, antara lain: 1) terbatasnya waktu, sehingga tim pengabdian masyarakat dalam menyampaikan tidak semua prosedur PTK dan teknik penulisan dapat dipraktikan oleh peserta terutama; 2) guru-guru 
dalam menyampaikan dan menuliskan permasalahan lebih banyak pada masalah yang makro menyangkut sekolah daripada masalah mikro yang ada di kelas mereka; 3) jika ada sebagian besar dari peserta yang antusias untuk menyimak, bertanya sekaligus berbagi atau berpendapat, tetapi ada juga yang masih malu untuk mengungkapkan permasalahannya dalam menghadapi permasalahan yang dihadapi di kelas; 4) ) guru dalam menyampaikan masalah cenderung pula peamasalahan lebih banyak kepada siswa; 5) guru-guru kabanyakan masih kurang banyak mengenal metode-metode pembelajran inovatif sekaligus media yang bisa dijadikan seebagai alternatif memecahkan permasalahan yang dihadapi ketika pembelajaran.

\section{Kesimpulan}

Kegiatan pengabdian kepada masyarakat ini cukup berhasil mewujudkan tujuan pengabdian sesuai yang diharapakan, meskipun belum sepenuhnya berhasil secara optimal. Ini dibuktikan dengan hasil yang dicapai selama berlangsungnya kegiatan, yaitu: 1) Pihak sekolah dalam hal ini kepala-kepala sekolah beserta guru-guru begitu bersemangat dan antusias mengikuti kegiatan. Hal ini ditunjukkan dari Perilaku mereka seperti untuk bertanya, menanggapi, berpendapat, bercerita pengalaman, meminta tindak lanjut dari kegiatan pengabdian kepada msyarakat terutama yang terkait penyusunan Penelitian Tindakan Kelas (PTK) dan teknik penulisan. Apalagi ada tunutang yang mewajiakan mereka untuk menyusun karya tulis ilmiah. 2) Pengabdian masyarakat ini tentan prosedur penyusunan proposal penelitian tindakan kelas (PTK). 3) Pandangan dari para peserta bahwa kegiatan ini sangat memberikan masukan yang cukup banyak untuk bisa menyusun proposal Penelitian Tindakan kelas (PTK) untuk mengembangkan profesi mereka ke depannya.

\section{Saran}

Saran yang dapat disampaikan dari kegiatan pengabdian kepada masyarakat bagi guru-guru MTS-MA di Kecamatan Woja Kabupaten Dompu antara lain: 1) Bagi Kemenag agama
Kabupaten/Provinsi. Perlunya dari pihak-pihak yang berkepentingan terhadap MTS-MA di Kecamatan Woja Kabupaten Dompu seperti Kemenag agama Kabupaten/Provinsi untuk megadakan kegiatan-kegiatan yang sejenis untuk lebih meningkatkan profesionalitas guru-guru MTS MTS-MA di Kecamatan Woja Kabupaten Dompu, 2) Bagi Sekolah. Pihak sekolah terutam kepalakepala sekolah untuk giat melakukan pelatihan yang sejenis agar para guru lebih profesional lagi dalam mengembangkan karirnya, 3) Bagi Guru. Guru terus berlatih jangan hanya menunggu jika ada kegiatan tertentu saja, tetapi bagaimana guru menangani suatu permasalahan dalam pembelajaran kemudian melakukan suatu tindakan.

\section{Daftar Pustaka}

Kemmis, s \& McTaggart,R. 1998. The Action Research Planner.3rd Ed. Victoria, Australia: Deakin University

Peraturan Menteri Negara Pendayagunaan Aparatur Negara (MENPAN) dan Reformasi Birokrasi Nomor 16 Tahun 2009

Sunyono. 2007. Modul Penelitian Tindakan Kelas (PTK).

Sujana, I Made. 2010. Workshop Penelitian Tindakan Kelas. Lombok: Arga Puji Press 